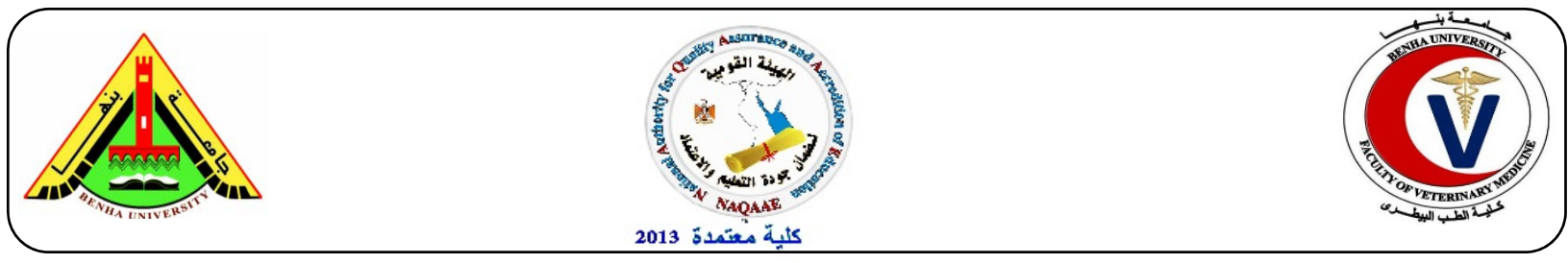

\title{
Bacteriological aspect of meat and poultry meat meals.
}

\author{
Fatin S. Hassanien ${ }^{1}$, Mohamed, A. H. El-Shater ${ }^{2}$, Rabab R. Abd El-Fatah ${ }^{3}$ \\ ${ }^{1}$ Department of Food Hygiene, Faculty of Veterinary Medicine, Benha University. ${ }^{2}$ Animal Health \\ Research Institute, Dokki, Giza,. ${ }^{3}$ Animal Health Research Institute, Benha.
}

\begin{abstract}
A B S T R A C T
Ninety random samples were collected from different restaurants in Benha city to evaluate their bacteriological quality. The mean values of APC, coliform, staphylococcus counts (cfu/g) were $2.69 \mathrm{x}$ $10^{5} \pm 0.47 \times 10^{5}, 5.54 \times 10^{3} \pm 0.96 \times 10^{3} \& 2.31 \times 10^{3} \pm 0.49 \times 10^{3}$ for beef kofta, $7.34 \times 10^{4} \pm 1.22 \times 10^{4}$, $1.73 \times 10^{3} \pm 0.51 \times 10^{3} \& 1.57 \times 10^{3} \pm 0.36 \times 10^{3}$ for beef burger, $3.16 \times 10^{4} \pm 0.60 \times 10^{4}, 1.01 \times 10^{3} \pm 0.27 \times$ $10^{3} \& 6.29 \times 10^{2} \pm 1.14 \times 10^{2}$ for beef shawerma, $6.23 \times 10^{5} \pm 1.14 \times 10^{5}, 8.52 \times 10^{3} \pm 2.04 \times 10^{3} \& 4.64 \times 10^{3} \pm$ $0.85 \times 10^{3}$ for chicken kofta,3.58 $\times 10^{5} \pm 0.72 \times 10^{5}, 2.39 \times 10^{3} \pm 0.61 \times 10^{3} \& 2.73 \times 10^{3} \pm 0.52 \times 10^{3}$ for chicken burger and $5.91 \times 10^{4} \pm 1.08 \times 10^{4}, 1.81 \times 10^{3} \pm 0.35 \times 10^{3} \& 9.42 \times 10^{3} \pm 2.23 \times 10^{3}$ for chicken shawerma, respectively. The results declared that 18 isolates of E.coli were identified from examined ready to eat meat and poultry meat meals with varying percentages. Accurately, $\mathrm{O}_{26}: \mathrm{H}_{11}, \mathrm{O}_{111}: \mathrm{H}_{4}, \mathrm{O}_{114}$ $: \mathrm{H}_{21}, \mathrm{O}_{128}: \mathrm{H}_{2}, \mathrm{O}_{124}, \mathrm{O}_{127}: \mathrm{H}_{6}, \mathrm{O}_{1}: \mathrm{H}_{7}, \mathrm{O}_{78}, \mathrm{O}_{125}: \mathrm{H}_{18}, \mathrm{O}_{78}, \mathrm{O}_{119}: \mathrm{H}_{4}$ E.coli strains were serologically identified from such examined samples. Also, 47 isolates of coagulase positive St.aureus were isolated from the examined ready to eat meat and poultry meat meals represented as $60 \%$ from beef kofta, $46.67 \%$ from beef burger, $40 \%$ from beef shawerma, $60 \%$ from chicken koft , 53.33\% from chicken burger, $53.33 \%$ from chicken shawerma samples.
\end{abstract}

Keywords: Poultry meat, E. coli, Meat products, S. aureus.

$$
\text { (http://www.bvmj.bu.edu.eg) conference issue }
$$

(BVMJ-28(2): 91-97, 2015)

\section{INTRODUCTION}

$\mathrm{R}$ eady - to - eat meat products are highly demanded due to their high biological value, reasonable price, agreeable taste and easily serving. Meat products are considered as excellent sources of high quality protein, minerals and vitamins (WHO, 1984 and Mosupy et al., 1998). Ready prepared foods are fried and usually held at room temperature for considerable period of time and later reheated without reaching the prescribed temperature. Usually, the poor quality raw materials of the meat products for street vendors as well as lack of necessary facilities to hold food within the recommended temperature, thus the existing microorganisms reach high levels sufficient to produce food borne diseases (Primo et al., 1993).

Using raw materials of poor microbial quality, inadequate personel hygiene and a long period between production and consumption at room temperature lead to contamination of food with pathogenic microorganisms, especially Salmonellae and coliform, posing potential risk to public health (Kiipliilii et al., 2003) as food infection or intoxication among consumers. Cooked poultry products may become a hazard when cross contamination from raw to cooked product occurred which is a major problem. The growth of food poisoning bacteria introduced in this way is not restricted by the competing organisms normally found in the raw product. Several 
foodborne illness with known etiological agents occurred where $6 \%$ were attributed to E. coli and 5\% to Staphylococcus aureus (Simone et al., 1997). S.aureus plays a great role in bacterial contamination of cooked meat because workers during preparation and processing may touch cooked meat that is usually eaten without sufficient cooking or heating (Soliman, 1988). Therefore, the present study was carried out for determination of APC, coliform \& Staphylococcus counts, isolation and identification of St.aureus, E. coli for ready to eat meat and poultry meat meals including beef kofta, beef burger, beef shawerm, chicken kofta, chicken burger, and chicken shawerma.

\section{MATERIAL AND METHODS}

\subsection{Collection of samples}

A grand total of 90 random samples of ready to eat meat and poultry meat meals including beef kofta, beef burger, beef shawerma, chicken kofta, chicken burger, and chicken shawerma (15 of each) were collected from different restaurants in Benha city. Each sample was kept in a separate sterile plastic bag, put in an ice box then transferred to the laboratory under complete aseptic conditions without undue delay for bacteriological examination.

\subsection{Preparation of samples (APHA, 1992)}

Twenty five grams of the samples were taken under aseptic condition to sterile stomacher bag then $225 \mathrm{ml}$ sterile $0.1 \%$ peptone water were added, the contents were homogenized at Stomacher for 2 minutes, the mixture was allowed to settled, for 5 minutes at room temperature. The contents were transferred into sterile flask, thoroughly mixed, $1 \mathrm{ml}$ was transferred into separate sterile test tube containing $9 \mathrm{ml}$ sterile $0.1 \%$ peptone water, from which tenth- fold serial dilutions were prepared.

\subsection{Bacteriological examination}

The prepared samples were subjected to the following bacteriological examination:
Determination of Aerobic Plate Count (FDA, 2001). Coliform count using Violet Red Bile agar medium (ICMSF, 1996). Isolation of E.coli (ISO, 2001): It was applied by using Macconkey broth as enriched borth and EMB as plating media. Serological Identification: The isolated strains of E.coli were identified serologically by using diagnostic sera "Welcome E.coli" agglutinating sera for diagnosis of the pathogenic types according to (Varnam-Evans, 1991). Determination of Staphylococci count using Mannitol agarplates(ICMSF, 1996). Isolation of St. aureus using Baired Parker agar (ICMSF, 1996).

\section{RESULTS}

The results of bacteriological examination of the ready to eat meat and poultry meat meals samples revealed that APC and coliform were highest in chicken kofta followed by chicken burger then beef kofta then beef burger then chicken shawerma then beef shawerma. While, staphylococcal count was highest in chicken shawerma followed bychicken kofta, chicken burger then beef kofta, beef burger and beef shawerma. In which, 47 isolates of coagulase positive St.aureus were isolated from the examined ready to eat meat and poultry meat meals represented as $60 \%$ from beef kofta , $46.67 \%$ from beef burger, $40 \%$ from beef shawerma, $60 \%$ from chicken koft, 53.33\% from chicken burger, $53.33 \%$ from chicken shawerma samples.

Isolation and identification of E. coli in the examined the ready to eat meat and poultry meat meals samples revealed that the incidence of $E$. coli was highest in beef burger then chicken kofta then chicken burger then beef shawerma then chicken shawerma, 18 isolates of E.coli represented as $33.33 \%$ from the beef kofta with serotypes $\mathrm{O}_{26}: \mathrm{H}_{11}(6.67 \%), \mathrm{O}_{111}: \mathrm{H}_{4}$ $(13.33 \%), \mathrm{O}_{114}: \mathrm{H}_{21}(6.67 \%)$ and $\mathrm{O}_{128}: \mathrm{H}_{2}$ (6.67\%). 26.67\% from beef burger with serotype $\mathrm{O}_{26}: \mathrm{H}_{11}(13.33 \%), \mathrm{O}_{111}: \mathrm{H}_{4}(6.67 \%)$ \& $\mathrm{O}_{124}(6.67 \%) .13 .33 \%$ beef shawerma, 
with serotypes $\mathrm{O} 111: \mathrm{H} 4(6.67 \%) \& \mathrm{O}_{127}: \mathrm{H}_{6}$ (6.67\%). 20\% from chicken kofta with serotypes $\mathrm{O}_{1}: \mathrm{H}_{7}(6.67 \%), \mathrm{O}_{78}(6.67 \%)$ \& $\mathrm{O}_{125}: \mathrm{H}_{18}(6.67 \%) .20 \%$ from chicken burger with serotypes, $\mathrm{O}_{78}(13.33 \%) \& \mathrm{O}_{127}: \mathrm{H}_{6}$ $(6.67 \%) \& 6.67 \%$ from chicken shawerma with serotypes $\mathrm{O}_{119}: \mathrm{H}_{4}(6.67 \%)$ only.

Table 1: Statistical analytical results of Aerobic plate counts (APC) (cfu/g) in the examined samples of ready to eat meat and chicken meat products $(n=15)$.

\begin{tabular}{lccc}
\hline product & Min. & Max. & Mean \pm S.E \\
\hline Meat products: & & & \\
kofta & $6.1 \times 10^{3}$ & $1.4 \times 10^{6}$ & $2.69 \times 10^{5} \pm 0.47 \times 10^{5}$ \\
burger & $3.2 \times 10^{3}$ & $3.7 \times 10^{5}$ & $7.34 \times 10^{4} \pm 1.22 \times 10^{4}$ \\
Meat shawerma & $1.5 \times 10^{3}$ & $8.8 \times 10^{4}$ & $3.16 \times 10^{4} \pm 0.60 \times 10^{5}$ \\
Chicken meat products: & & & \\
kofta & $2.4 \times 10^{4}$ & $1.5 \times 10^{6}$ & $6.23 \times 10^{5} \pm 1.14 \times 10^{5}$ \\
burger & $5.1 \times 10^{3}$ & $9.2 \times 10^{5}$ & $3.58 \times 10^{5} \pm 0.72 \times 10^{5}$ \\
shawerma & $4.0 \times 10^{3}$ & $1.7 \times 10^{5}$ & $5.91 \times 10^{4} \pm 1.08 \times 10^{4}$ \\
\hline
\end{tabular}

S.E $E^{*}$ standard error of mean

Table 2: Statistical analytical results of total coliform counts (cfu/g) in the examined samples of ready to eat meat and chicken meat products $(\mathrm{n}=15)$.

\begin{tabular}{lccccc}
\hline \multirow{2}{*}{ product } & \multicolumn{2}{c}{ +ve Samples } & \multirow{2}{*}{ Min. } & \multirow{2}{*}{ Max. } & \multirow{2}{*}{ Mean \pm S.E } \\
\cline { 2 - 3 } & No & $\%$ & & \\
\hline Meat products: & 13 & 93.33 & $1.0 \times 10^{2}$ & $9.8 \times 10^{3}$ & $5.45 \times 10^{3} \pm 0.96 \times 10^{3}$ \\
kofta & 11 & 73.33 & $1.0 \times 10^{2}$ & $4.8 \times 10^{3}$ & $1.73 \times 10^{3} \pm 0.51 \times 10^{3}$ \\
$\quad$ burger & 9 & 60.00 & $1.0 \times 10^{2}$ & $4.0 \times 10^{3}$ & $1.01 \times 10^{3} \pm 0.27 \times 10^{3}$ \\
Meat shawerma & & & & & \\
Chicken meat products: & 14 & 86.67 & $2.0 \times 10^{2}$ & $3.4 \times 10^{4}$ & $8.52 \times 10^{3} \pm 2.04 \times 10^{3}$ \\
kofta & 11 & 73.33 & $1.0 \times 10^{2}$ & $6.8 \times 10^{3}$ & $2.39 \times 10^{3} \pm 0.61 \times 10^{3}$ \\
$\quad$ burger & 10 & 66.67 & $1.0 \times 10^{2}$ & $5.0 \times 10^{3}$ & $1.81 \times 10^{3} \pm 0.35 \times 10^{3}$ \\
shawerma & & & & &
\end{tabular}

Table 3: Incidence and serotyping of Enteropathogenic E.coli isolated from the examined samples of ready to eat meat products $(\mathrm{n}=15)$.

\begin{tabular}{lccccccc}
\hline \multirow{2}{*}{ E.colistrains } & \multicolumn{2}{c}{ Kofta } & \multicolumn{2}{c}{ Burger } & \multicolumn{2}{c}{ Shawerma } & \multirow{2}{*}{ Strain Characteristics } \\
\cline { 2 - 6 } & No. & $\%$ & No. & $\%$ & No. & $\%$ & EHEC \\
$\mathrm{O}_{26}: \mathrm{H}_{11}$ & 1 & 6.67 & 2 & 13.33 & - & - & EHEC \\
$\mathrm{O}_{111}: \mathrm{H}_{4}$ & 2 & 13.33 & 1 & 6.67 & 1 & 6.67 & EPEC \\
$\mathrm{O}_{114}: \mathrm{H}_{21}$ & 1 & 6.67 & - & - & - & - & EIEC \\
$\mathrm{O}_{124}$ & - & - & 1 & 6.67 & - & - & ETEC \\
$\mathrm{O}_{127}: \mathrm{H}_{6}$ & - & - & - & - & 1 & 6.67 & ETEC \\
$\mathrm{O}_{128}: \mathrm{H}_{2}$ & 1 & 6.67 & - & - & - & - & \\
Total & 5 & 33.33 & 4 & 26.67 & 2 & 13.33 &
\end{tabular}

$\overline{\mathrm{EPEC}}=$ EnteropathogenicE.coliETEC $=$ EnterotoxigenicE.coli, EIEC $=$ EnteroinvasiveE.coliEHEC $=$ Enterohaemorrhagic E.coli.

Table 4: Incidence and serotyping of Enteropathogenic E.coli isolated from the examined samples of ready to eat chicken meat products $(n=15)$.

\begin{tabular}{lccccccc}
\hline \multirow{2}{*}{ E. coli strains } & \multicolumn{2}{c}{ Kofta } & \multicolumn{2}{c}{ Burger } & \multicolumn{2}{c}{ Shawerma } & \multirow{2}{*}{ Strain Characteristics } \\
\cline { 2 - 6 } & No. & $\%$ & No. & $\%$ & No. & $\%$ & EPEC \\
$\mathrm{O}_{1}: \mathrm{H}_{7}$ & 1 & 6.67 & - & - & - & - & EPEC \\
$\mathrm{O}_{78}$ & 1 & 6.67 & 2 & 13.33 & - & - & ETEC \\
$\mathrm{O}_{125}: \mathrm{H}_{18}$ & 1 & 6.67 & - & - & - & - & EPEC \\
$\mathrm{O}_{119}: \mathrm{H}_{4}$ & - & - & - & - & 1 & 6.67 & ETEC \\
$\mathrm{O}_{127}: \mathrm{H}_{6}$ & - & - & 1 & 6.67 & - & - & \\
Total & 3 & 20.00 & 3 & 20.00 & 1 & 6.67 & \\
\hline
\end{tabular}


Table (5) Statistical analytical results of total Staphylococci counts (cfu/g) in the examined samples of ready to eat meat and chicken meat products $(n=15)$.

\begin{tabular}{lccccc}
\hline & \multicolumn{2}{c}{ tve Samples } & & \\
\cline { 2 - 3 } product & No & $\%$ & Min & Max & Mean \pm S.E \\
\hline Meat products: & 12 & 80.00 & $1.0 \times 10^{2}$ & $5.0 \times 10^{3}$ & $2.31 \times 10^{3} \pm 0.49 \times 10^{3}$ \\
kofta & 11 & 73.33 & $1.0 \times 10^{2}$ & $4.0 \times 10^{3}$ & $1.57 \times 10^{3} \pm 0.36 \times 10^{3}$ \\
burger & 10 & 66.67 & $1.0 \times 10^{2}$ & $9.0 \times 10^{2}$ & $6.29 \times 10^{2} \pm 1.14 \times 10^{2}$ \\
Meat shawerma & & & & & \\
Chicken meat products: & 12 & 80.00 & $1.0 \times 10^{2}$ & $8.0 \times 10^{3}$ & $4.64 \times 10^{3} \pm 0.85 \times 10^{3}$ \\
kofta & 12 & 80.00 & $2.0 \times 10^{2}$ & $5.0 \times 10^{3}$ & $2.73 \times 10^{3} \pm 0.52 \times 10^{3}$ \\
burger & 11 & 73.33 & $1.0 \times 10^{2}$ & $2.0 \times 10^{3}$ & $9.42 \times 10^{3} \pm 2.23 \times 10^{3}$ \\
shawerma & & & & & \\
\hline
\end{tabular}

${\mathrm{S} . \mathrm{E}^{*}}^{*}$ standard error of mean.

Table 6: Incidence of Gram positive cocci isolated from the examined samples of ready to eat meat products $(n=15)$.

\begin{tabular}{lcc}
\hline & \multicolumn{2}{c}{ +ve Samples } \\
\cline { 2 - 3 } product & No & $\%$ \\
\hline Meat products: & 9 & 60.00 \\
kofta & 7 & 46.67 \\
burger & 6 & 40.00 \\
Meat shawerma & & \\
Chicken meat products: & & 60.00 \\
kofta & 9 & 53.33 \\
burger & 8 & 53.33 \\
shawerma & 8 & \\
\hline
\end{tabular}

\section{DISCUSSION}

The total aerobic plate count is important for evaluation of sanitary condition of ready to eat meat and poultry meat products. Limits suggested for total aerobic bacterial count in various foods range from $10^{5}$ to $10^{7}$ microbes /g. (EEC, 2005). The data shown in Table (1) revealed that, the mean value of $\mathrm{APC} / \mathrm{g}$ in the examined samples $2.69 \times 10^{5} \pm 0.47 \times 10^{5}$ for beef kofta, $7.34 \times 10^{4} \pm 1.22 \times 10^{4}$ for beef burger, $3.16 \times 10^{4} \pm 0.60 \times 10^{4}$ for beef shawerma, $6.23 \times 10^{5} \pm 1.14 \times 10^{5}$ for chicken kofta, $3.58 \times 10^{5} \pm 0.72 \times 10^{5}$ for chicken burger and $5.91 \times 10^{4} \pm 1.08 \times 10^{4}$ for chicken shawerma, respectively. These results were lower than those suggested by by ElTaher-Amna (2009) who found that APC in the examined samples of cooked kofta was $5.38 \times 10^{4}(\mathrm{cfu} / \mathrm{g})$. Nearly similar results were obtained by by EEC 2005, Tolba (1994), who found that APC in the examined samples of kofta was $2.9 \times 10^{5} \pm 1.9 \times 10^{5} / \mathrm{g}$. Meanwhile, higher figures were recorded by Hussein (1996), Rafaie and Mostafa (1990) who Found that the mean APC in the examined samples of shawerma collected from various fast food restaurants was $2.46 \times 10^{7}(\mathrm{cfu} / \mathrm{g})$. Although, the aerobic plate counts of any food articles are not a sure indicative of their safety for consumption, yet it is of supreme importance in judging the hygienic condition under which food has been produced, handled and stored (Levine, 1987). Accordingly the high bacterial count of some examined samples may be attributed to neglected sanitary measures during their processing, handling, serving of such products. The variation in bacterial count between different types of meat products could be attributed to difference of ingredients and steps involved in their formulation and preparation (Hefnawy and Youssef, 1984).

Data presented in Table (2) showed that the mean values of coliform count ( $\mathrm{cfu} / \mathrm{g}$ ) in the examined samples were $5.45 \times 10^{3} \pm$ $0.96 \times 10^{3}$ for beef kofta, $1.73 \times 10^{3} \pm$ $0.51 \times 10^{3}$ for beef burger, $1.01 \times 10^{3} \pm$ $6.27 \times 10^{3}$ for beef shawerma, $8.52 \times 10^{3} \pm$ $2.04 \times 10^{3}$ for chicken kofta, $2.39 \times 10^{3} \pm$ $0.61 \times 10^{3}$ for chicken burger and $1.81 \times 10^{3} \pm$ $0.35 \times 10^{3}$ for chicken shawerma. The current results agree with those recorded by El-Rayes (2008) and Yassien (1992) who found that the mean value of coliform was $3.8 \times 10^{3} / \mathrm{g}$ in the examined cooked meat samples. While, lower results were recorded by Elwi (1994), Saad et al. (2011) 
who found that the mean value of coliform was $5.17 \times 10^{2} \pm 1.2 \times 10^{2} / \mathrm{g}$ in the examined samples of grilled beef kofta. However, higher findings were obtained by Rafaie and Moustafa (1990) who found that the mean value of coliform was $33.9 \times 10^{5} / \mathrm{g}$ for shawerma samples, Hussien (1996) who found that the mean value of coliform count was $1.8 \times 10^{5}$ for kofta sandwiches. The high incidence of coliforms in the examined ready-to-eat sandwiches indicates inadequate processing or post processing contamination (most probably from workers, dirty instrument, machinery and other contact surfaces), or from raw ingredients before processing which drive their contamination from various sources as human contact, polluted water, soil and manure, The presence of coliforms indicates a probable faecal sources of contamination (Thatcher and Clark, 1975; ICMSF, 1978 and NAS, 1985). The results in tables $(3 \& 4)$ revealed that, 18 isolates of E.coli were isolated from examined samples represented as $33.33 \%$ from the beef kofta with serotypes $\mathrm{O}_{26}: \mathrm{H}_{11}(6.67 \%), \mathrm{O}_{111}: \mathrm{H}_{4}$ (13.33\%), $\mathrm{O}_{114}: \mathrm{H}_{21} \quad(6.67 \%) \quad \& \quad \mathrm{O}_{128}: \mathrm{H}_{2}$ (6.67\%), 26.67\% from beef burger with serotype $\mathrm{O}_{26}: \mathrm{H}_{11}(13.33 \%), \mathrm{O}_{111}: \mathrm{H}_{4}(6.67 \%)$ \& $\mathrm{O}_{124}(6.67 \%), 13.33 \%$ beef shawerma, with serotypes $\mathrm{O}_{111}: \mathrm{H}_{4}(6.67 \%) \& \mathrm{O}_{127}: \mathrm{H}_{6}$ $(6.67 \%), 20 \%$ from chicken kofta with serotypes $\mathrm{O}_{1}: \mathrm{H}_{7}(6.67 \%), \mathrm{O}_{78}(6.67 \%) \quad \&$ $\mathrm{O}_{125}: \mathrm{H}_{18}(6.67 \%), 20 \%$ from chicken burger with serotypes, $\mathrm{O}_{78}(13.33 \%) \& \mathrm{O}_{127}: \mathrm{H}_{6}$ $(6.67 \%) \& 6.67 \%$ from chicken shawerma with serotypes $\mathrm{O}_{119}: \mathrm{H}_{4}(6.67 \%)$ only. Such Enteropathogenic E.coli were previously isolated from different ready-to-eat meat products by Yassien (1992), Soliman and El-Tabiy (2006) and El-Rayes (2008) who achieved that the incidence of serologically identified $E$-coli isolated from the examined samples of kofta were 5 isolates . In general, EPEC strains are the major cause for many infantile diarrhea, in typical cases, symptoms appear within 12 to 36 hours. Clinically, EPEC illness is characterized by fever, nausea, vomition and watery stools, which occasionally contain mucous, but without gross blood (Toledo et al., 1983).Certain serotypes of E.coli play an important role as human pathogens, which give rise to gastroenteritis outbreaks, severe diarrhea in infants, coli-bacillosis in adults, meningitis, enteritis (Youssef et al., 1992). The obtained results in Table (5) revealed that, the mean value of Staphylococcus count $(\mathrm{cfu} / \mathrm{g}) 2.31 \times 10^{3} \pm 0.49 \times 10^{3}$ for beef kofta, $1.57 \times 10^{3} \pm 0.36 \times 10^{3} /$ for beef burger, $6.29 \times 10^{2} \pm 1.14 \times 10^{2}$ for beef shawerma, $4.64 \times 10^{3} \pm 0.85 \times 10^{3}$ for chicken kofta, $2.73 \times 10^{3} \pm 0.52 \times 10^{3}$ for chicken burger and $9.42 \times 10^{3} \pm 2.23 \times 10^{3}$ for chicken shawerma. Nearly similar results obtained by Nasser (1988); Yassien El-Essawy (1990) and Moussa et al. (1992) who found that the mean values of St-aureus count $(\mathrm{cfu} / \mathrm{g})$ was $5.8 \times 10^{4}$ in the examined samples of ready to eat meat. While Mohamed (2000) failed to detect and isolate $S$. aureus from any of the examined samples of heat treated meat products, also lower result recorded by Zaki (2003) \& Abd Allah and Hassan (2000) who found that the mean value of staphylococci count was $1.2 \times 10^{2}(\mathrm{cfu} / \mathrm{g})$ in the examined samples of cooked shawerma. However, higher findings were obtained by Kirralla (2007) \& Al-Tawwab (2004) who found that the mean value of staphylococcus aureus count was $3.1 \times 10^{6} \pm 4.9 \times 10^{5}, 5 \times 10^{4} \pm$ $6.7 \times 10^{3}$ in the examined samples of kofta and shawerma, respectively. The results obtained in tables $(6,7)$ revealed that 47 isolates of coagulase positive St.aureus were isolated from the examined ready to eat meat and poultry meat meals represented as $60 \%$ from beef kofta, $46.67 \%$ from beef burger, $40 \%$ from beef shawerma, $60 \%$ from chicken koft ,53.33\% from chicken burger, $53.33 \%$ from chicken shawerma samples. Such organism was previously isolated from ready-to-eat meat products by Soliman et al. (2002) \& Kirralla (2007) who isolate S. aureus from cooked meat samples. The presence of $S$. aureus in a food indicates its contamination from food handlers and inadequately cleaned equipments (ICMSF, 1996). Finally, the present study proved that ready to eat meat 
and poultry meat meals constitute public health hazard. The presence of negligible percentages of aerobic bacteria, Enterobacteriaceae, coliforms, E.coli, Staphylococci mainly Coagulase Positive $S$. aureus was due to the post-cooking contamination with bad handling, added spices and during packaging.

\section{REFERENCES}

Abd Allah, W.H., Hassan, A.A. 2000. Sanitary status of some ready to eat meat meals in Cairo and Giza Governorates. J. Egypt. Vet. Med. Ass. 60(7):95-104.

Al-Tawwab, M. 2004.Safety of street vended meat meals exposed to the open environment. M.V. Sc. Thesis (Meat hygiene), Fac. Vet. Med., Zagazig University.

American Public Health Association "APHA"1992 .Compendium of Methods for the Microbiological examination of Foods. $3^{\text {rd }}$ Ed. (carl, v). The American Public Health Association, DC.

El-Rayes, A.M.A. 2008. Incidence of pathogenic Escherichia coli in fast foods. M.V.Sc. Thesis, Fac. Vet. Med, Benha University.

Elwi, E.M. 1994. Sanitary improvement of meat meals in governmental hospitals in Assiut City. Ph. D. thesis, Meat Hygiene, Fac. of Vet. Med; Assiut University.

EEC 2005. Commission regulation (EC) No.2073/2005 on microbiological criteria for foodstuffs. Council of the European Communities (EEC). Off. J. Eur. Commu.1.338:22.

Food and Drug Administration "FDA"2001. Center for Food safety and applied nutrition. (www.FDA. org.).

Hefnawy, Y.A., Youssef, H.H. 1984. Microbiological evaluation of some selected spices. Assuit Vet. Med. J. 13(25):145-149.
Hussein, M.I. 1996. Microbial evaluation of some meat meals of Assiut restaurants. M.V.Sc. Thesis, Fac. of Vet. Medicine Assiut University.

International commission of Microbiological Specification for Foods (ICMSF) 1978. Microorganisms in food, their significance and methods of enumeration, $2^{\text {nd }} \mathrm{Ed}$. Univ. of Toronto Press, Toronto and Buffalo, Canda.

International commission of Microbiological Specification for Foods $\quad 1996$. Microorganisms in Food. I-Their Significance and methods of enumeration. $3^{\text {rd }}$ Ed. Univ. of Toronto, Canada.

International Organization of Standardization "ISO"2001. Microbiology of food, animal feeding stuffs. Horizontal method for the enumeration of $\beta$ - glucuronidasPositive E-Coli. Part 2: ColonyCount technique at $44^{\circ} \mathrm{c}$ using 5 bromo-4-chloro-3- indolyl $\beta$-Dglucuronide. 16649-2.

Kiipliilii, B., Sarimehmetoglu, B., Oral, N. 2003. The microbiological quality of Cig kofta sold in Ankara. Turk VeterinerlikveHayvancilikDergisi 27(2):325-329.

Kirralla, G.A. 2007. Sanitary status of meat meals of students of Tanta University. M.V. Sc. Thesis meat hygiene, Fac. Vet. Med., kafr El Shickh University.

Levine, M.M. 1987. Escherichia coli that cause diarrhea: enterotoxigenci, enteropathogenic, enteroinvasive, enterohaemorrhagic enteroadherant. J. Infect. Dis. 155:377-389.

Mohamed, E.N. 2000. Quality investigation into beef frankfurter produced in Egypt. M.V. Sc., Thesis, Fac. Vet. Med., Cairo Univ.

Mosupy, F.M., Arntzen, L., Von Holy, A. 1998. Microbiological survey of street-vended food in the Johannesburg metropolitan area of 
South Africa. Food Sci, 63(7):842 846.

Moussa, M.M., Samaha, I., El daly, E., Salah, E. 1992. Occurrence of certain food poisoning organism in some ready-to-eat food. Egypt. J. Appl. Sci., 1(2):21.

Nassar, A.M. 1988. Sanitary status of meat meals in Assuit University hospitals. M.V. Sc. Thesis, Meat Hygiene, Assuit Univ. Egypt.

National Academy of Science "NAS" 1985. An evaluation of the role of microbiological criteria for foods and food ingredients. National Academy Press, Washington D.C.

Primo, A., Claudio, R., Jaun, C., Albins, J. 1993. Street food vending in latin America. Proc. $11^{\text {th }}$ Inter. Sump. WAVFM 24(29): 405.

Rafaie, R.S., Mostafa, S. 1990. Microbiological quality of shawarma in Assuit. Vet. Med. J. 24(47):135.

Saad M.S., Hemat, M.I., Enas A.M.A. 2011.Microbial and chemical evaluation of fast foods. J. Benha vet. Med. S.E (1):44-51.

Simone, E., Goosen, M., Notermans, S.H.W., Borgdorff, M.W. 1997. Investigation of food borne diseases by food inspection service in the Netherlands, 1991-1994. Journal of Food Protection, 60(4):442-446.

Soliman, M.R. 1988. Sanitary status of ready to eat meat products and fishes. M.V.Sc. Thesis, Fac. Vet. Med. Cairo Univ.

Soliman, M.R., Abd El-Monem, K.M., Saad, S.M. 2002. Microbiological quality of ready-to-eat meat products and fishes in urban and rural areas. J. Egypt. Vet. Med. Assoc. 62(6): 39-51.

Soliman, Z.I., El-Tabiy, A.A. 2006. A study on the occurrence of Escherichia coli in some beef products with special references to E.coliO157:H7AssiutVet-Med-J., 52(110):75-87.

Thatcher, F.S., Clark, D.S. 1975. Microorganisms in Food, I. International committee on microbiological specification for foods. Univ. of Toronto press, Tronto and Buffalo, CanadaEl-Taher-Amna, M. 2009. Impact of temperature abuse on safety of food offered in a University Student Restaurant. M.V. Sc. Thesis, Meat Hygiene, Fac. of Vet. Med., Moshtohor Benha Univ.

Toledo, M.R.F., Alvariza, M.C.B., Murahovschi, J., Sramos, S.R.T., Trabulsi, L.R. 1983. Enteropathogenic Escherichia coli serotypes and endemic diarrhea in infants. Infect. Immun. 39:586 - 589.

Tolba, K.S. 1994. Microflora in locally processed frozen meat. Vet. Med. J. Giza, 42(2):99.

World Health Organization 'WHO' 1984. The role of food safety in health development. Report of Joint FAO/WHO Expert Committee on Food Safety, Geneva.

Yassien, N.A. 1992. Enter pathogenic E.coli in a food serving establishment. Fleischwirtschaft. 12: 5.

Zaki, E.M. 2003. Risk assessment of ready prepared meat products. Ph. D. Thesis, Meat Hygiene. Fac. Vet. Med., Cairo University. 